\title{
Protesting iconic megaprojects. A discourse network analysis of the evolution of the conflict over Stuttgart 2 I
}

Urban Studies

2019, Vol. 56(8) I68I-1700

(c) Urban Studies Journal Limited 2018 Article reuse guidelines: sagepub.com/journals-permissions DOI: $10.1177 / 0042098018775903$ journals.sagepub.com/home/usj @SAGE

\author{
Melanie Nagel \\ University of Constance, Germany
}

\section{Keiichi Satoh}

University of Constance, Germany

\begin{abstract}
The past decades witnessed enormous transformations in the built environment of cities, and one of these trends is the development of iconic megaprojects. Public protests against these projects occur frequently, and scholars in urban governance have diagnosed this as an emerging 'postpolitical' condition, that is, as a sign of a deficient democratic politics. Others criticise this kind of reasoning as a 'post-political-trap' (Beveridge and Koch, 2017), and demand more research. This article responds to this debate with an empirical study of the popular protests against the infrastructural public transport project Stuttgart 2I in Germany. We apply discourse network analysis to investigate the evolution of the discourse, illuminate multiple dynamic connections between issues and actors, and apply factor analysis to identify the key issues of the conflict. Our study complicates and qualifies the arguments for a 'post-political' state of urban politics.
\end{abstract}

\section{Keywords}

built environment, discourse network analysis, infrastructural projects, networks, planning, policy, transport

摘要

过去几十年，城市建筑环境发生了巨大变化，其中一个趋势是标志性大型项目的开发。针 对这些项目的公开抗议活动频繁发生，城市治理学者将此视为一种正在出现的“后政治”状 况, 即民主政治不足的标志。其他人则批评这种推理是“后政治陷阴” (Beveridge和Koch, 2017），并且需要更多的研究。本文通过对德国公共交通基础设施项目 “斯图加特 21 ” 的 群众抗议活动进行实证研究, 回应了这场争论。我们运用 “话语网络分析” 来研究话语的 演变, 阐明问题与行动者之间的多重动态联系, 并应用因素分析来确定冲突的关键问题。 我们的研究将关于城市政治“后政治”状态的争论推向更为深入复杂、引入更多限制条件的 阶段。

\section{关键词}

建筑环境、话语网络分析、基础设施项目、网络、规划，政策，交通 
Received January 2016; accepted April 2018

\section{Introduction}

Research on urban politics and urban governance has grown over the last three decades (MacLeod, 2011), mirroring the immense transformations undergone by cities themselves. One of these trends is 'a proliferation of megaprojects of iconic development and associated infrastructures' (MacLeod, 2011: 2630; see also Douglass and Huang, 2007; Graham and Marvin, 2001; Young and Keil, 2010). Over the course of the last two decades protests and discontent in the context of the planning and building of mega urban infrastructure projects have become a common occurrence, and scholars attribute such public resistance to democratic deficits and limited opportunities for public participation (Marres, 2005, cited in Legacy, 2016). Most strategic urban megaprojects currently under construction are, according to Moulaert et al. (2001), dominated by 'neoliberal' efforts by 'eliteformations' to build 'the entrepreneurial city'. Other scholars also criticise the lack of democratic consultation and the absence of coherent social policy to guide new urban development politics, as well as the lack of integration of megaprojects in urban processes and planning systems (cf. Moulaert et al., 2003; Salet, 2008; Swyngedouw et al., 2002; cf. Graham and Marvin, 2003).

In this article, we challenge the prevailing view of the post-democracy argument that democratic deficits alone are to blame for strong discontent and polarisation. We analyse the conflict surrounding the planned construction of an underground railway station in the city of Stuttgart, Germany, whose tracks when completed will serve high speed regional and European express and local commuter trains, turning Stuttgart into an important transport hub situated in the heart of Europe. The name for the proposed project, Stuttgart 21 (S21), soon became a synonym for the German word 'Wutbürger', which means 'furious citizens'. The infrastructural project was discussed emotionally, protests were staged, and things reached a peak when the protests escalated violently between protestors and the police on 30 September 2010. While this appears in line with the 'democratic deficits' view, a referendum held later in November 2011 showed that, in fact, most citizens were pro S21. The incongruity between the vehemence of the protests and majority support (as demonstrated by the referendum results) bears explaining. This paper applies insights drawn from theories of discourse coalitions to an empirical study that combines discourse analysis and network analysis. By analysing major newspaper accounts of diverse groups of actors (including organisations, social movements, civil society groups, and political parties) over a ten-year period, and by using factor analysis, our empirical study shows which actors were involved at what time, and which issues were important to them.

Thus, the study contributes to studies on urban governance, one of the key concepts of urban studies (McCann, 2017). The key question of governance is not only why cities are the way they are now, but also '[...] how they are made to be the way they are, through the concerted actions of the state, other public and private institutions, social movements,

\section{Corresponding author:}

Melanie Nagel, Department of Public Policy and Administration, University of Constance, Fach D8I, Konstanz 72I60, Germany.

Email: melanie.nagel@uni-konstanz.de 
civil society and the practices of everyday life' (McCann, 2017: 313). The governance approach focuses on the ability of political actors to act, and therefore it is closely related to policy output (cf. Gissendanner, 2004: 47). The case of S21 belies the claims of recent literature on the post-political condition (Mouffe, 2005; Rancière, 2001), especially in urban studies, which argues that the new discourse platforms created alongside the state are signs of shifted politics, that is, a resistance to the state's inability to take popular preferences into account (Blühdorn, 2013; Boland, 2014; Bylund 2012; Oosterlynck and Swyngedouw, 2010). The post-political framing of urban infrastructures introduces according to Legacy (2016) a strong contrast between state planning and citizens' counteraction, and other scholars argue that the lack of transparency and lack of democratic control in the development of iconic megaprojects 'play a crucial role in the erosion of democracy' (Vento, 2017: 68). The expressions 'postdemocracy' (Crouch, 2004), 'post-politics' (Mouffe, 2005) or 'post-political' (Rancière, 2009) illustrate '[...] a contemporary democratic condition in which genuine contestation and conflicting claims [...] are not apparent' (Beveridge and Koch, 2017: 32-33).
However, our study of S21 shows that there is no straightforward link between citizen protest and democratic deficits, and that, instead of a tendency toward elite-formation as scholars have warned, popular and elite preferences were in fact aligned. Thus, it affirms some of the criticisms made of the 'post-political-trap' (Beveridge and Koch, 2017).

This paper is structured as follows. In the first section, an overview of the history of S21, the main actors and their particular positions, and a review of scholarly approaches will be given. The next part introduces the general theoretical approach of discourse network analysis. Then, we explain the different steps of the data collection process, selection of the data sources, coding procedure, and introduce the method of the discourse network analysis, before presenting the findings. First, we explain who the important actors and discourse coalitions are and point out their positions visualised in an actor-by-issue network. In the second part, we present the factor analysis of issue-by-issue networks and the entanglement of issues connected to these actors. Lastly, we recap our findings and conclude with a discussion of how these findings

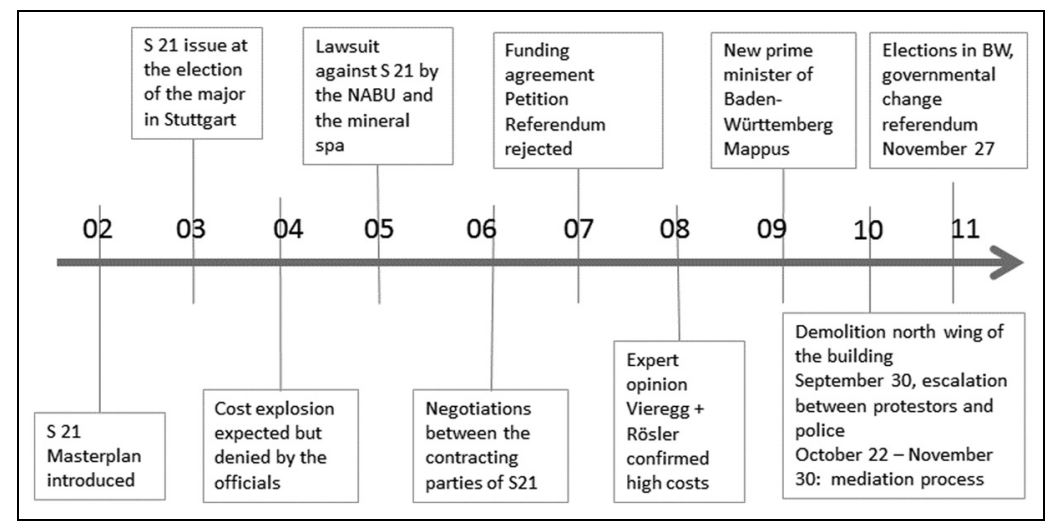

Figure I. Timeline of the key events of the project Stuttgart 21 . Source: Nagel (2016: 156; graphics modified). 
contribute to urban studies literature by challenging the argument of post-democracy and post-politics.

The time frame of this study ranges from 2002 until 2011, for two reasons: analysing the policy process by means of a policy analysis requires a time span of at least 10 years (e.g. Jenkins-Smith et al., 2014) and in our case study, different crucial phases, as explained in the subsequent part, could be identified during that time. Figure 1 shows a timeline of the major events.

\section{Brief history of Stuttgart 2 I}

S21 is an ambitious infrastructural project by the biggest railway company in Germany, Deutsche Bahn (DB), the city of Stuttgart, the state Baden-Württemberg and the German Federal Republic. The southern German city of Stuttgart is situated near the geographical centre of Europe and the planned railway connection is part of the Magistrale for Europe - a high-speed railway track between Paris, Strasbourg, Stuttgart, Ulm, Munich, Vienna and Bratislava. A rapid transit route from Wendlingen to Ulm, two other cities in Germany, is also included in this project.

In the 1990s, big urban infrastructure projects were planned in almost every metropolitan region in Europe, and what Banister and Hall (1993) call the 'second railway age', with inner-city railway stations surrounded by other buildings and infrastructure, became the centre of ambitious urban redevelopment plans. The planning of S21 started in the 1990s with a proposal by the traffic expert Gerhard Heimerl. In 1994, the project S21 was presented to the public and in 1997, the master plan for the city of Stuttgart was developed. The infrastructural project was the main issue of the mayoral (Oberbürgermeister) elections in Stuttgart in 2003 and in 2004, because of cost explosions forecasted by various experts, which officials denied. The environmental organisation NABU (acronym for Naturschutzbund Deutschland, 'Nature Protection Alliance Germany') and the Mineralbad Berg (Berg mineral spa, a public swimming pool) went to court against the project in 2005, without success. In 2006, negotiations between DB, the state government of Baden-Württemberg and the city of Stuttgart were held, followed by a funding agreement in 2007, which was passed with a total budget of $€ 4.8$ billion. In 2006, 67,000 people signed a petition against this project, and weekly demonstrations in Stuttgart drew many thousands of protestors.

The situation escalated in October 2010: thousands were protesting in the Palace Park, when the conflict between protestors and police escalated. Images of the police using water cannons against protestors, including elderly people and children, were broadcast on media nationwide. This shocking event gained nationwide attention, and led to a mediation process, which lasted from 22 October to 30 November 2010.

In March 2011, a new BadenWürttemberg Parliament, consisting of a coalition of the Green Party and the Social Democrats, was elected, toppling the incumbent CDU (Christlich Demokratische Partei or Christian Democratic Party). The Fukushima nuclear catastrophe and discontent with the S21 project were among the reasons why voters decided to drop the former conservative government after 58 years of dominance. A few months later, the newly elected government fulfilled its campaign promise to hold a referendum on S21. In November 2011, in the state of BadenWürttemberg, a majority of citizens surprisingly voted in favour of S21.

To put it in a nutshell, S21 is not only a modernisation of the old railway station, it is an enormous financial investment, passionately opposed by environmental activists and civil society groups, but, surprisingly, favoured by many citizens. From this brief 
history, several questions arise: Why did this project become the subject of such heated debate? How can we explain the evolution of this emotional and polarised process? Which lessons can be learned for other megaprojects and the diagnosis of post-democracy?

Urban transport planning is inherently political', with priority settings and decisions on huge investments that serve some groups better than others (Legacy, 2016: 3108). Studies of S21 scrutinise the emphasis on justice sensitivity (Rothmund et al., 2014), the use of Twitter for the organisation of collective action (Jungherr and Jürgens, 2014), Facebook activities of proponents and opponents (Maier, 2013), voting behaviours and the NIMBY effect (cf. Vatter and Heidelberger, 2013). The most comprehensive discussion of the conflict over Stuttgart 21 and the inherent fundamental disagreement over future urban planning and transportation policy, costs and benefits of these expensive megaprojects and the procedures of democratic decision-making is by Novy and Peters (2013). Using a similar case of public protests against an airport expansion, Eike-Christian Hornig (2017) refers to the Political Opportunity Structure Approach and offers a new model called Vertically Asymmetric Policies (VAPs) to explain the 'democratic dilemma of multi-level politics between system effectiveness and citizen participation' (Hornig, 2017: 325). Our paper builds on these studies, and likewise asks questions concerning democracy and participation. However, our study carries out a more in-depth analysis of the evolution of the discourse to disclose the underlying beliefs and ideas driving the public and visible actions and statements.

We therefore focus on a multidimensional perspective, which carries out a dynamical analysis of actors, their issues of concern, and the connections amongst issues and actors over a period of ten years. The evolution of the conflict over a long period enables us to see changes to discourses over time, and offers a more nuanced overview of actors and issues. The combined analysis of actors as well as the different issues that connect them allows us to get to the heart of the conflict, and to address several dimensions of urban conflict in a single analysis. Third, ideas and beliefs play an important role in policy-making (Bradford, 2016: 659), and discourse network analysis contributes to our understanding of the role they play. This perspective (and its associated methodology) is still underdeveloped in urban politics. Finally, we apply a new and innovative approach of discourse network analysis to a complex issue in urban politics, which allows us to trace the main lines of contention and dissent, without oversimplifying.

\section{Discourse coalitions: Theory and methods}

To understand urban governance in the context of thorny problems and complex policy initiatives, Neil Bradford (2016) argues that under conditions of uncertainty, ideas play an important role 'in motivating collective action, channelling policy resources, and shaping prospects for collaboration' (Bradford, 2016: 660). He proposes an analytical framework called discursive localism for a better understanding of politics and policy in cities. That is, when issues are highly complex and uncertain, and the time window is especially long, government constellations alternate and change (Bradford, 2016: 659), not just in relation to these longterm issues, but also as short-term strategic considerations, such as before elections.

The 'argumentative turn' in political and social sciences has shown that ideas and beliefs play an important role for collective action and the channelling of policy resources. Different groups of actors are involved in the decision process, and their unique underlying ideas and perceptions take 
discursive shape. According to discourse analysis (Hajer, 1993, 1995, 2002) and discursive institutionalism (Schmidt, 2008; Schmidt and Radaelli, 2004), the political process can be seen as a struggle over discursive hegemony between conflicting discourse coalitions (Leifeld and Haunss, 2012). The groups of actors that share the same framework of interpretation and ideas are called discourse coalitions (e.g. Bulkeley, 2000; Fischer and Forester, 1993; Hajer, 1993, 1996, 2002; Szarka, 2004), and within any society, several discourse coalitions always struggle for discursive hegemony (Muller, 2015).

The discourse theoretical approaches are derived mainly from Michel Foucault's work on post-structuralism and Jürgen Habermas' communicative discourse ethics. 'Discourse theory starts from the assumption that all actions, objects, and practices are socially meaningful and that these meanings are shaped by the social and political struggles in specific historical periods' (Fischer, 2003: 73). This article uses Maarten Hajer's Discourse Coalitions approach $(1995,2002)$, which advocates investigating language and text analysis, as well as the analysis of the constellations of actors. If a discourse coalition wants to be successful, it has to dominate the public discourse, and its dominance will be reflected by institutional practices in the political domain (Hajer, 1993: 48). The dominant coalition is prominent in the media, and is therefore able to integrate its core frames into a consistent storyline, which is superior to the storyline of its opponents.

This paper maps discourse coalitions by means of discourse network analysis, which combines discourse analysis and policy network analysis. By policy network we mean all actors who participate in the public policy process, as well as the relations amongst these actors. These are not only actors of the government and parliament, but also, because of resource dependence and interest interrelations, a variety of heterogenic actors hailing from civic and non-governmental organisations and interest groups (Kenis and Schneider, 1991).

\section{Method}

To measure and visualise the evolution of a particular political discourse, such as S21, researchers have employed a tool called discourse network analysis (see Janning et al., 2009; Leifeld, 2009, 2010, 2012, 2013). Discourse network analysis is a dynamical and longitudinal analysis of political discourse (Leifeld, 2010: 13). It is an approach that combines qualitative content analysis and quantitative social network analysis, and at the same time offers a new possibility for conceptualising and measuring the 'coevolution of actors and concepts in a dynamic way' (Leifeld, 2010: 4). Social network analysis serves as an analytical toolbox for relational analysis (Kenis and Schneider, 1991), and policy debates can be operationalised by aligning the actors by their common claims (Koopmans and Statham, 1999). Furthermore, both approaches integrate actors and concepts (Leifeld and Haunss, 2012: 389).

Graph theory and matrix algebra serve as a foundation for many conceptualisations of social network analyses (Hage and Haray, 1983; Iacobucci, 1994). Actors and relations between them are modelled by graphs consisting of nodes, which are connected by edges. In other words, the nodes represent actors (e.g. organisations, persons, companies), and the edges represent relations (e.g. exchange of knowledge, exchange of money, sharing the same beliefs).

As described in detail by Leifeld and Haunss (2012: 390ff) and Leifeld (2013: 174), a discourse network has the basic form of an affiliation network. The visualisation of the network is a graph with actors as vertices and the number of shared issue positions as edge weights between them (Fisher 
et al., 2013: 530). The basic matrix is an actor-by-concept affiliation matrix, which is converted into a square matrix (co-occurrence matrix) where all actors (rows and columns in the matrix) are connected by the number of their shared concepts. In the cells of the matrix, 0 stands for no shared common concept, numbers ( 1 to $n$ ) in the cells for shared common concepts and the diagonal entries are left blank. There are shared common concepts if both agree or disagree on one or more concepts (categories of statements). These co-occurrence networks are interpreted as undirected and weighted according to the number of shared concepts. The visualisation with network diagrams of discourse networks is thus a good opportunity to operationalise policy discourses.

\section{Data collection}

The data collection consists of newspaper articles on 'Stuttgart 21' published in four different German newspapers from 2002 through 2011. ${ }^{1}$ The software program Discourse Network Analyzer ${ }^{2}$ (or DNA) was used for organising and coding the data. This computer program allows the quantitative coding of actors and their statements, and offers the possibility of exporting network data for the visualisation of the relationships between actors in a discourse field, and how they are connected by shared arguments. For the discourse network analysis, we chose different steps for collecting the data. The key issues are the selection of the time frame, the newspaper source, and the coding procedure, which will be explained below.

Collecting data from newspaper media is a popular and easily available source for analysing social events (Earl et al., 2004). This simple access to big data sources, with daily up-to-date availability, offers the possibility of analysing dynamical data over many years. Many scholars use newspaper data (e.g. Franzosi, 1987; Koopmans and Rucht,
1999; Rucht et al., 1999). Nevertheless, it should not be forgotten that newspaper content is not created for the purpose of social scientific research (see Ortiz et al., 2005: 397). Questions of reliability and validity have to be taken into account, and the advantages and disadvantages of newspaper data have to be considered (Baumgarten and Grauel, 2009). Factors including the intensity of an event, conflicting elements, and the significance of actors involved could increase media attention. Media structure and media outlets could also influence individual newspaper issues, as might be found in the case of attention cycles, which refer to the phenomenon whereby certain issues gain prominence for a period of time before fading into obscurity (McCarthy et al., 1996; McCombs and Shaw, 1972). Newspaper data are but one discursive arena among many (Hilgartner and Bosk, 1988), and the question is if this arena is representative of all the others (Baumgarten and Grauel, 2009). For a dominant issue, such as the case of S21, the number of articles should be sufficient to comprehensively investigate the public media discourse. The descriptions of the selection methods in the following sections consider these limiting factors, the possible effects of biases in our study, and possible limitations of our findings.

\section{Selected time frame and newspaper sources}

To obtain sufficient data on phases of political emergence and maturing of the issue, escalations during the protests, governmental changes, and public participation (as explained earlier in the history of S21), we selected a time span from 2002 until 2011. The selection of the newspapers was determined by the following considerations. First, whether they were available in digital full-text archives; second, if they corresponded to the 'quality press criterion' (Barranco and Wisler, 1999; Koopmans, 1996; Kriesi, 1995; 
Leifeld, 2013), that is, they must fulfil conditions of a wide publication range, political moderation, and a good reputation. The data collection consists of newspaper articles on 'Stuttgart 21' in four different German newspapers: two regional newspapers (Stuttgarter Nachrichten and Stuttgarter Zeitung) and two national newspapers (Frankfurter Allgemeine Zeitung and Süddeutsche Zeitung).

All articles were selected if they contained the search term 'Stuttgart 21' in the title or the first lines, and if they were relevant for the case. This means that all articles dealing with the issue S21 were selected, except for articles describing, for example, a theatre play dealing with S21. In total 556 articles dealing with the case of S21 were selected, each of which comprises more than 500 words.

\section{The coding procedure}

For the coding procedure four kinds of information were coded: the statement, the name of the actor, the organisation the actor belongs to, the category the statement belongs to, and a dichotomous variable 'agreement' or 'disagreement'. The categorisation of the statements was coded manually using predefined codes (deductive coding) and expanded during the coding procedure (inductive coding) (for more details of the coding process, see Nagel, 2016).

Researcher-bias through coding and data entry errors is a critical point, because the coding procedure requires an accurate and intensive coordination as well as theoretical and conceptual clarity. The question of whether content analysis data is reliable has to be answered by content analysis methodologists at all times. The underlying problem is called intercoder reliability (Franzosi, 2004: 182). Random errors (reliability) from newspaper data and non-random errors (validity) occur and have to be limited and, if possible, eliminated. Franzosi (2004: 183) recommends focusing on the validation of the data through alternative and independent measures. One scientist coded all the data in this study, which might pose a problem of reliability rather than of validity. Our attempt to reduce this bias was to have another scientist randomly control the data, and in case of deviation, a solution was discussed and noted in the codebook.

Overall, 556 articles, with 2077 statements were coded (see Figure 2 coded categories and number of statements). These statements were coded into 155 categories, which were divided into 34 meta-categories for factor analysis (see meta-categories in Table 1; a detailed overview of all categories and meta-categories is in the Appendix, available online).

\section{Research findings}

This article explores how the evolution of the polarised debate on S21 can be understood, also, in the light of a post-democracy debate. As noted above, the complex case of S21 was coded into 155 different categories of arguments, divided into 34 different metacategories. Figure 2 shows the coded categories and number of statements.

\section{Actors and discourse coalitions}

This study identified 319 persons belonging to 91 organisational actors engaged in policy

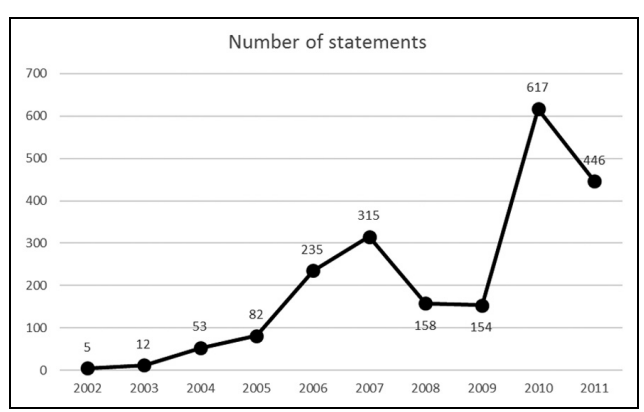

Figure 2. Coded categories and number of statements.

Source: Author's own graphics. 


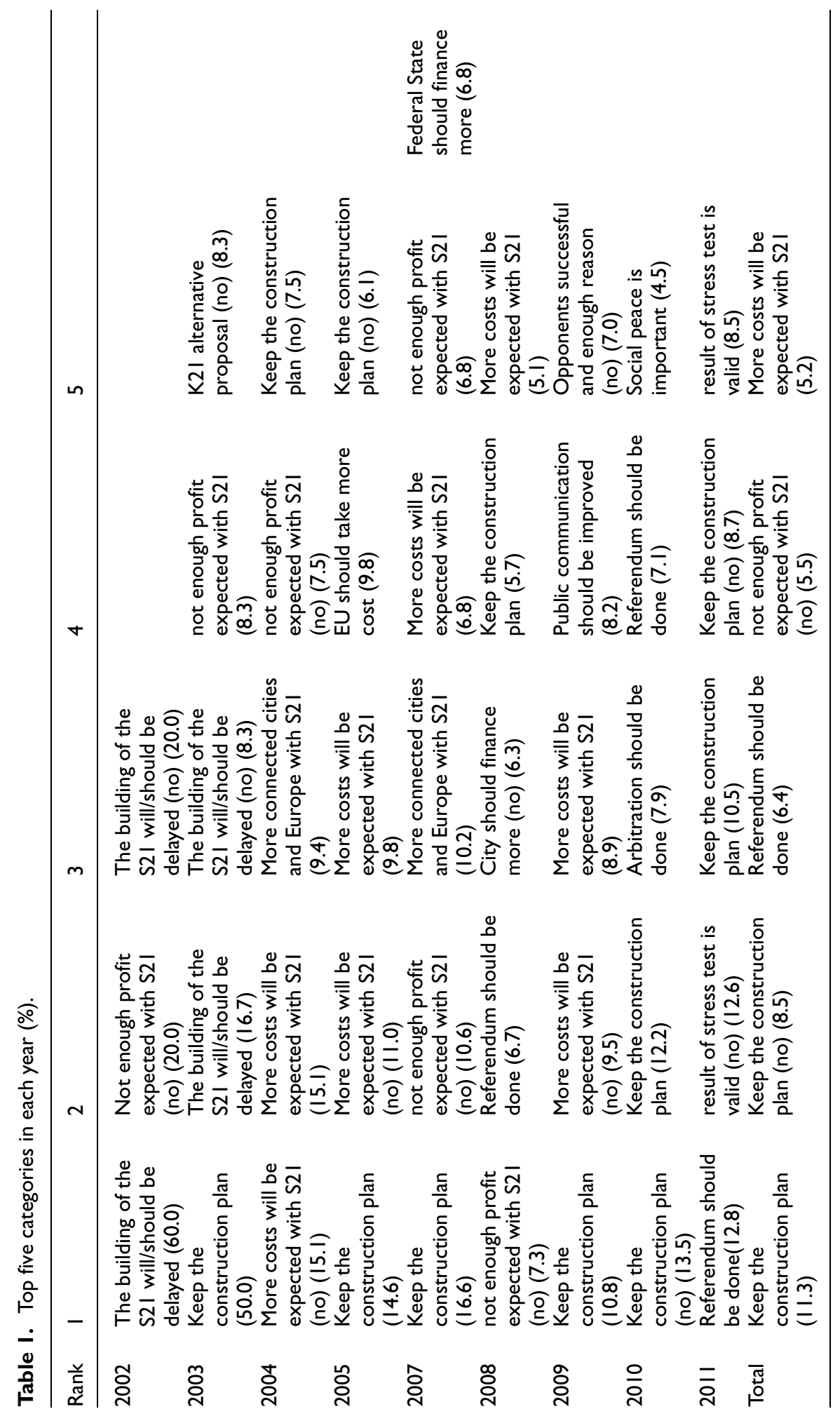


discourse between 2002 and 2011. These actors were included when they made at least one statement in one or more of the 556 newspaper articles concerning S21. We argue that all actors appearing in the media are important for the issue of S21, since they will warrant mention in the media if they are important to the case. These actors belong to various political parties, organisations, social movements, associations, or DB.

\section{Central actors and their positions}

There are two central groups of actors: opponents and proponents of the project (see Appendix, available online, for the entire list of the actors involved in this analysis). Table 2 shows the most important groups or organisations and their respective positions. The importance and relevance of these actors is assessed on the basis of their frequent occurrence in the newspaper articles analysed. All underlying information comes from newspaper articles and website research. There are actors from both sides, pro and contra S21: political parties, social movements and civil society groups, associations, and officials of the DB.

Opponents of Stuttgart 21. The opponents of S21 are a heterogeneous group of actors, mostly environmental activists, traffic clubs, left-wing and green political parties and civil society groups, all allied in their opposition to the infrastructural project. Opponents of S21 demanded a different model called 'Railhead 21' (Kopfbahnhof 21). This alternative model proposed a renovation of the current railway station and the building of a few new railway tracks. According to the S21 opponents, the costs would be less expensive than the underground construction, and the performance could possibly be better than the planned S21 station. Additionally, it would allow railway tracks to travel through the station, but would contain only eight instead of 16 platforms. Klaus Arnoldi, a politician and S21 opponent, stated: 'Instead of a $33 \mathrm{~km}$ tunnel, as seen in Stuttgart 21, only a ten $\mathrm{km}$ tunnel-route was planned, which would be cheaper and associated with lower cost risks' (statement of Klaus Arnoldi, in Stuttgarter Zeitung, 30 January 2007; all statements translated by authors).

The following statements illustrate the opponents' views: 'The only problem is that the reconstruction simply cannot be financed' (statement of Boris Palmer, politician, in Stuttgarter Zeitung, 26 October 2006). 'One cannot cut back on regional trains and simultaneously strive for a project devouring billions', argued Gerhard Pfeifer, managing director of the BUND-regional-union. Or, as Boris Palmer put it: 'My great concern is that the Prime Minister, as well as the mayor of Stuttgart, Wolfgang Schuster, want to enforce Stuttgart 21 by all means, just for the sake of the reputation and the prestige of Stuttgart' (in Stuttgarter Zeitung, 26 October 2006).

In October 2007, a broad range of citizen and environmental organisations, supporters of the Green Party and grassroots initiatives such as 'Living in Stuttgart' organised a petition and public demonstrations. This petition was signed by 67,000 people, and the political struggle over whether the matter could be decided by a local referendum began. Legal experts denied the validity of the referendum, arguing that the project was not only financed by the city of Stuttgart but that it was not for the city to make the final decision.

When the protests against the project escalated in 2010, a mediation procedure gave both sides the opportunity to submit their arguments in a moderated and publicly broadcast process. In March 2011, the elections, strongly influenced by the controversial issue and the Fukushima nuclear accident in Japan, swept the Green Party and Social Democrats into power, and brought about institutional change and a supposed harmonisation in the polarised 


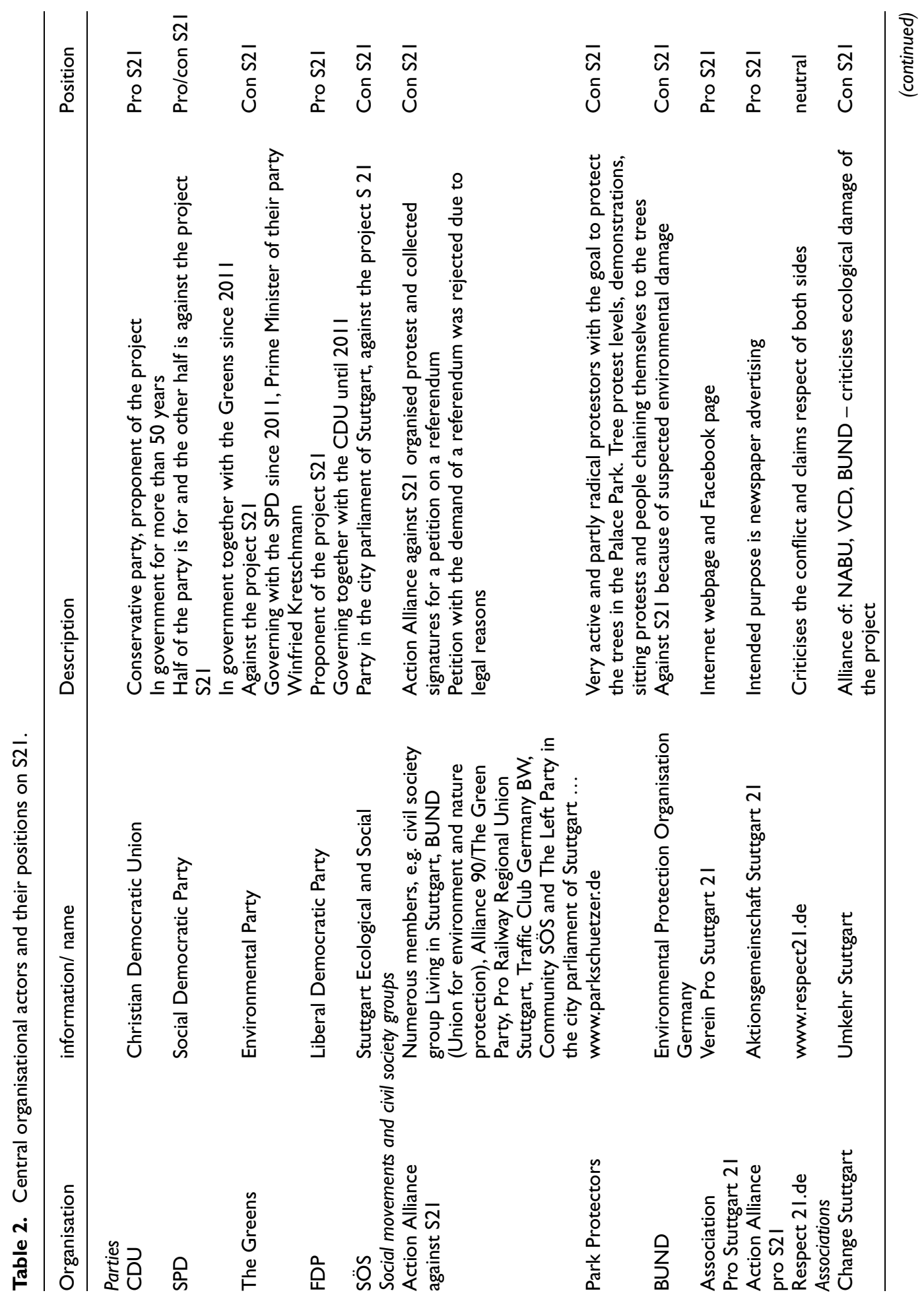




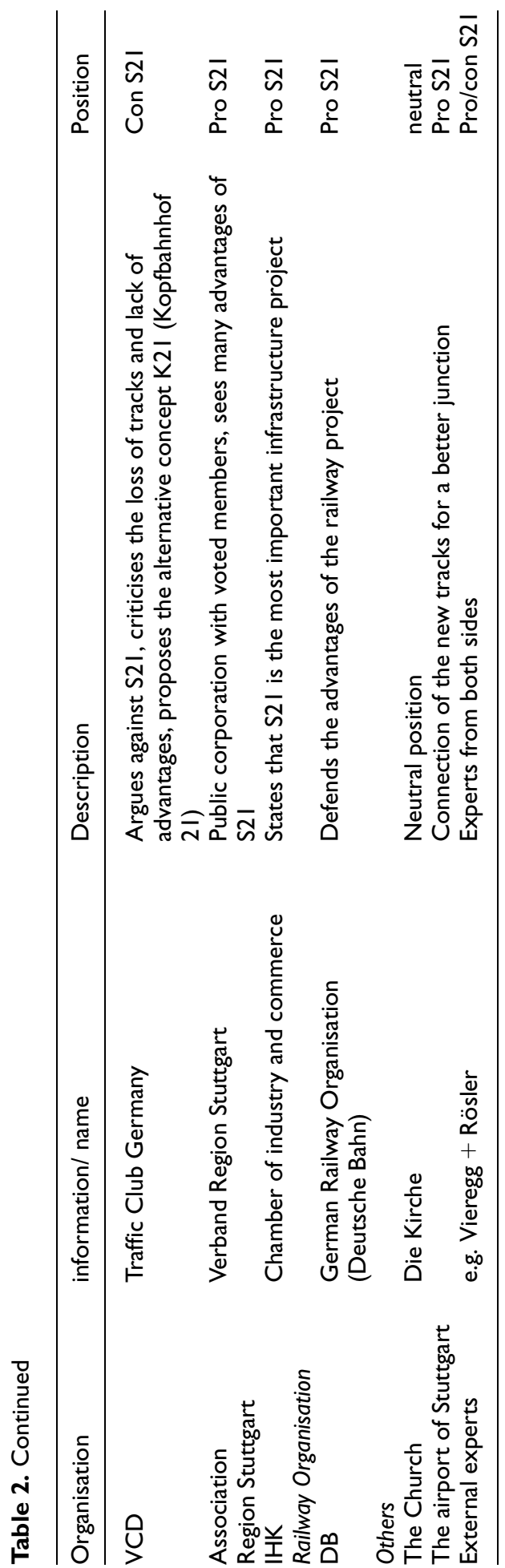

discourse (Nagel, 2016). In November 2011, a state-wide referendum was held. The outcome was that the required quorum for halting the project was not achieved - which means most of the citizens, surprisingly, voted in favour of S21.

The proponents of Stuttgart 2I. The actors supporting S21 consist mainly of the conservative political parties CDU and FDP (Freie Demokratische Partei or Liberal Democratic Party), the Chamber of Industry and Commerce, the Association Region Stuttgart, the Association Pro Stuttgart 21, and the Action Alliance Pro S21. They back the plan for a new railway station, the underground construction of tracks, and the infrastructural project in general. They are especially interested in new possibilities for urban development and the building of a valuable new inner-city quarter, made possible by the demolition and underground replacement of tracks. They reject the alternative model Railhead 21 because, as Ulrich Müller, Minister of Transport for BadenWürttemberg, explained, 'What critics misjudge: Incredibly large investments would be needed to preserve the status quo, for example for the modernization of railway control centres. To our knowledge approximately 800 Million $€$ would be needed - without the benefits of Stuttgart 21' (in Stuttgarter Zeitung, 18 February 2004). Sebastian Sage, architect and S21 supporter, was of the opinion that 'If Stuttgart 21 was rejected, another ten years without any improvements around the railway node in Stuttgart would be lost' (in Stuttgarter Zeitung, 5 October 2006).

To sum up, by unpacking the content of the discourse over Stuttgart 21, we could find out more about different views advanced by opponents and proponents of S21, and the different priorities and visions that guide their arguments. Opponents feared cost explosions, environmental damage and loss of control over decisions on 
urban planning. They were frustrated with the current political establishment and called for more public participation. Proponents were annoyed by the protestors, and feared the state parliament would lose control over the decision process, as well as the stagnation of future infrastructural investments.

Our empirical findings show that the fundamental disagreement is only partly connected to the wish for more public participation, and other issues play a crucial role. ${ }^{3}$ This empirical finding is in contrast to the commonly used explanation in urban studies literature, that is, a lack of transparency and democratic control (Vento, 2017: 68).

A further question remains, namely, of how these coalitions and issues have developed over time. The next section analyses the discourse network data and explores the evolution of discourse coalitions over time.

\section{Evolution of the discourse}

To trace the evolution of perspectives on the controversial issue, we now focus on the above-mentioned meta-categories of the discourse.

Looking at the number of statements in each year, we recognise the following considerations. First, the number of statements increased in 2010, which suggests that S21 became an increasingly important issue in public discourse. Second, when looking at the trend, two peaks can be found - the first in 2007 and the second in 2010. Now, to have a closer look at the discourse coalitions

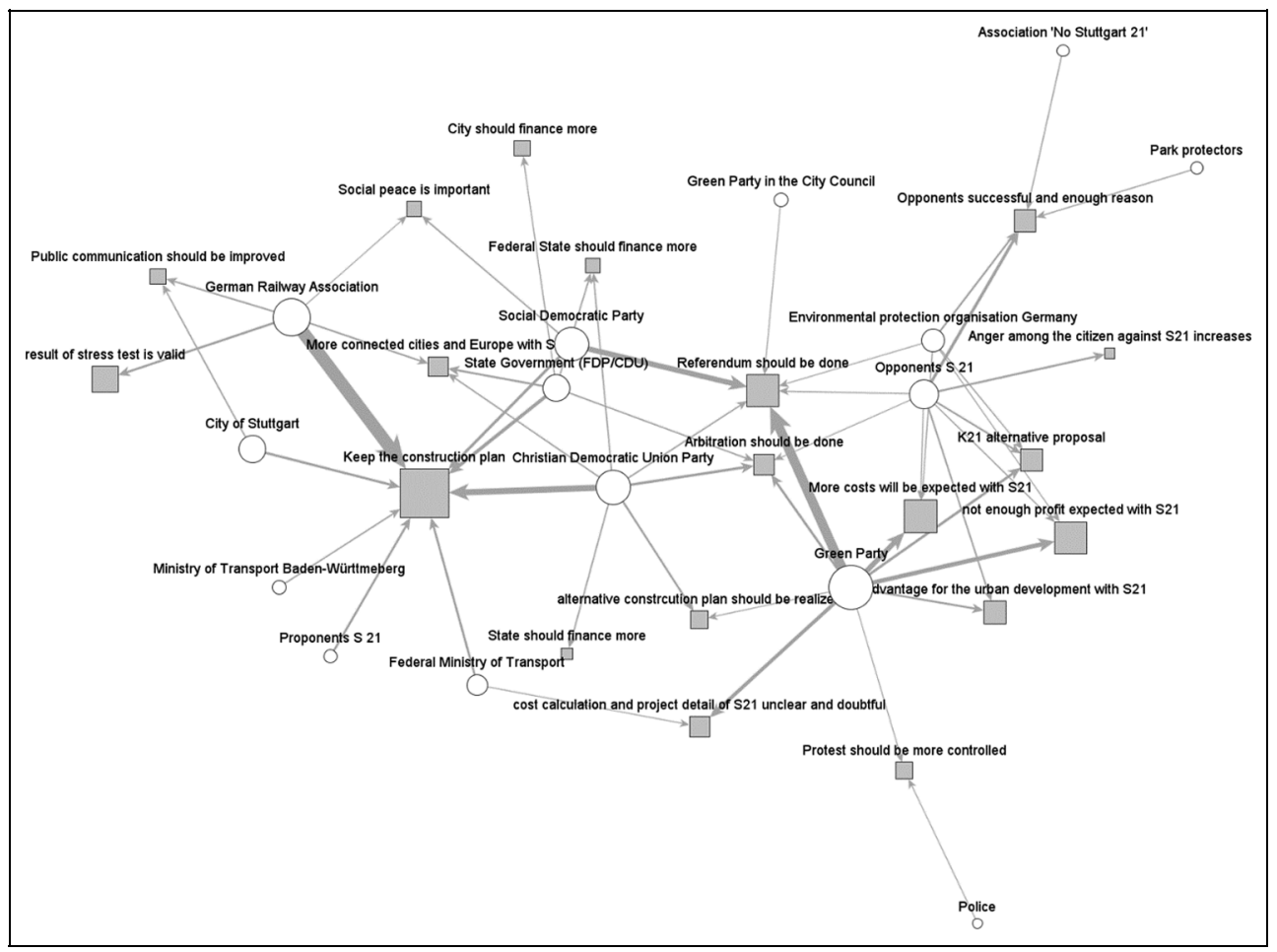

Figure 3. Actors and issues more or equal to 5. Source: Author's own visualisation with Visone. 
and their relevant issues, they will be illustrated in the following discourse networks (see Figure 3).

\section{Discourse actors and relevant issues}

By visualising the actor-by-category network, the discourse network approach allows us to analyse actors and categories in one graph. The round nodes represent the actors and the quadrangular nodes symbolise the issues; the size of the nodes shows their respective importance. The width of the lines shows the weight of their relations - thin lines mean that there are only five common issues or actors, whereas thick connections represent strong relations with many shared issues. We have to note that the Visone-algorithm ${ }^{4}$ places the nodes next to similar nodes, and with its quick-layout function $^{5}$ produces a reasonable layout. According to the similarity and size of the nodes, we can interpret the visualisation below as follows. The central actors are the CDU and the DB with their common issue 'Keep the construction plan', and the SPD and the Green Party with their shared issue 'Referendum should be done'.

This visualisation reveals the connections between actors and issues, but on closer inspection, we have to analyse how the contents of the discussions developed over time. To do so, we will more closely examine the top five categories of issues each year in the following section.

When looking at the top five categories each year, we discover the following. First, in 2002, objections against the construction were stated, and since 2004, the costs of the construction have become the main issue of the dispute. Furthermore, in the first peak in 2007, the financial issue including the costs and profits of the construction was the issue mentioned the most. From 2008 onwards, the idea of the referendum became more common. Gradually opinions on the construction became highly polarised, especially in 2009, when the top issue was the retention of the construction plan, but the second and third issues concerned disputes over the expected costs. Next, in 2010, the discussion about how to reach a consensus given the polarised views ('arbitration should take place') became more common. Finally, in 2011, the issue 'referendum should be done' was the third most common.

\section{Factor analysis of categories and actors}

Factor analysis identifies the most important issues for the actors, the crucial dimensions of the conflict. In the previous section, we have seen that the various statements (including the execution of the plan, cost of the construction, and idea of a referendum) were interconnected, and have ebbed and flowed in importance during the period under investigation. Now, the question remains of how these diverse statements are connected to one other. How can we get the macro view on how the discussions evolved?

To answer the question, we calculated a factor analysis. In our data, each organisation's statement is coded with 1 if the organisation agrees with the statement, and -1 if they disagree with it. We aggregated the categories by organisation, which means by the direction in which the relevant organisation is headed. Based on this aggregated data, we conducted a factor analysis, with a minimum residual solution with an oblimin rotation, using the $\mathrm{R}$ package psych $\mathrm{v}$. 1.6.12 (Revelle, 2016).

The following two main factors were identified (Table 3). Factor 1 consists of statements such as 'Keep the construction plan', 'More connected cities and Europe with S21', and 'Public communication should be improved'. Overall, the statements with a large loading on Factor 1 are those, which stress the importance of S21 and urge its 
Table 3. The results of factor analysis.

\begin{tabular}{|c|c|c|}
\hline & $\mathrm{FCl}$ & FC2 \\
\hline $\begin{array}{l}\text { Keep the construction plan } \\
\text { More connected cities and Europe with S2I } \\
\text { Public communication should be improved } \\
\text { Result of stress test is valid } \\
\text { Federal State should finance more } \\
\text { Social peace is important } \\
\text { Should take account of the other projects } \\
\text { State should finance more } \\
\text { In the future no major project, if S2I not realised } \\
\text { More public transportation use promoted through S2I } \\
\text { Cost calculation and project detail of S2I unclear and doubtful } \\
\text { DB should take more cost } \\
\text { Compensation for the cancelled resources } \\
\text { No advantage for the urban development with S2I } \\
\text { K2I alternative proposal } \\
\text { The building of the S2I will/should be delayed } \\
\text { Not enough profit expected with S2I } \\
\text { No further financial agreement }\end{array}$ & $\begin{array}{r}0.88 \\
0.85 \\
0.73 \\
0.67 \\
0.67 \\
0.59 \\
0.57 \\
0.57 \\
0.43 \\
0.41 \\
-0.50 \\
-0.50 \\
-0.66 \\
-0.71 \\
-0.80 \\
-0.82 \\
-0.92 \\
-0.94\end{array}$ & $\begin{array}{r}-0.33 \\
0.13 \\
0.33 \\
-0.46 \\
0.20 \\
0.49 \\
0.22 \\
0.13 \\
-0.32 \\
-0.08 \\
0.69 \\
-0.16 \\
-0.25 \\
0.29 \\
0.37 \\
-0.26 \\
0.24 \\
-0.11\end{array}$ \\
\hline $\begin{array}{l}\text { Quorum of plebiscite too high } \\
\text { Arbitration should be done } \\
\text { More costs will be expected with S2I } \\
\text { Referendum should be done } \\
\text { Alternative construction plan should be realised } \\
\text { Protest should be more controlled } \\
\text { City should finance more } \\
\text { Despite the S2I, the ruling party can win the election } \\
\text { Container village will be built }\end{array}$ & $\begin{array}{r}-0.26 \\
0.43 \\
-0.37 \\
-0.11 \\
0.27 \\
0.27 \\
-0.08 \\
0.41 \\
-0.38\end{array}$ & $\begin{array}{r}0.91 \\
0.85 \\
0.82 \\
0.85 \\
0.58 \\
0.46 \\
-0.42 \\
-0.55 \\
-0.88\end{array}$ \\
\hline $\begin{array}{l}\text { S2I should be stopped to save old trees } \\
\text { Opponents successful and enough reason } \\
\text { Campaign for S2I } \\
\text { Anger among the citizens against S2I increases } \\
\text { EU should take more cost } \\
\text { Involved should take the cost } \\
\text { Other cities should finance more }\end{array}$ & $\begin{array}{r}-0.32 \\
-0.19 \\
0.16 \\
-0.13 \\
0.32 \\
0.07 \\
0.01\end{array}$ & $\begin{array}{r}0.33 \\
0.21 \\
0.04 \\
0.21 \\
-0.30 \\
-0.25 \\
-0.01\end{array}$ \\
\hline $\begin{array}{l}\text { Loadings } \\
\text { Proportion of variation }\end{array}$ & $\begin{array}{l}9.95 \\
0.29\end{array}$ & $\begin{array}{l}6.99 \\
0.21\end{array}$ \\
\hline Correlation between factors & -0.14 & \\
\hline
\end{tabular}

Note: Factors were calculated by minimum residual solution with oblimin rotation by R package psych v.I.6.I2 (Revelle, 2016).

construction. Therefore, we name Factor 1 as the 'Progress of S21' factor. Organisations that have a large positive score in Factor 1 argue for the construction of S21, while organisations that have negative value argue for the halt of the construction of S21.
Factor 2 consists of the statements calling for a referendum ('Referendum should be done') or are about the ways in which the referendum should be implemented ('Quorum of plebiscite too high'). Accordingly, we consider this factor as 
'Implementation of Referendum'. Those organisations having positive values on this score argued for the need of the Referendum. Quite interestingly, the metacategory 'More costs will be expected' also belongs to this factor, suggesting that the actors who argued about the referendum also saw the rise in costs as particularly problematic. Citizens who were against the project because of the cost explosion called for a referendum, in order to determine the legitimacy (or lack thereof) of the project.

It should be also noted that the metacategory 'Protest should be more controlled' also belongs to this factor with plus $(+)$ loading. This suggests that some actors arguing over the referendum also saw the heated protests as problematic.

The correlation between Factor 1 ('Progress of S21') and Factor 2 ('Implementation of Referendum') was relatively low $(r=-0.14)$. This suggests that the discussions about the construction of S21 and the implementation of the Referendum belonged to different dimensions in the discussion.

This is a very suggestive result for understanding why the increasing intensity of the protests against S21, and the support for S21 at the referendum, occurred simultaneously. Some actors discussed S21 from the perspective of the construction and its advantages, in other words, from the perspective of growth, as shown in Factor 1. Other actors questioned the legitimacy of the plans, or viewed them from the perspective of democracy. These two dimensions (growth and democracy) widened the range of people who consider S21 as problematic, and the discussions therefore expanded.

\section{Discussion and conclusion}

Megaprojects and their focus on expertise and technocracy, as well as populist opinions, play a crucial role in the "erosion of democracy and the establishment' (Vento, 2017: 68). Literature in the field of urban governance and politics has recently warned of a post-democratic or post-political consensus (MacLeod, 2011), but scholars also criticise such theorisations, calling them a 'post-political trap' (Beveridge and Koch, 2017). While the post-political perspective addresses important developments in urban politics, its explanatory power is, in our view, limited, especially with regards to megaprojects. The democratic deficits observed by post-democratic scholars (cf. Crouch, 2004) charge that societies have become less democratic, but they fail to account for the multiple modes in which 'democracy' and democratic participation and legitimation may be made manifest or expressed. We believe that cognitive and ideational perspectives especially (cf. Bradford, 2016) should be examined for a better understanding of collaborative urban governance and its multiple modes of actualisation, and this is what our paper attempts to illuminate through its empirical investigation of an urban conflict case study using discourse network analysis.

To give a more nuanced understanding, we begin by presenting the history and narratives of the case study Stuttgart 21, which is an iconic megaproject in the city of Stuttgart, Germany. The protests against this infrastructural project, the violent escalation between protestors and the police, the fierce opposition between the conflicting coalitions, appear to fulfil the diagnoses of theories of the 'post-political': they represent the citizens' rejection of the political establishment, their strong discontent with political decision processes, and demands for participation.

Our study traced the evolution of the key actors and coalitions in the discourse, and our factor analysis identified the most important factors or dimensions of the conflict: on the one hand, the perspective of 
growth, and on the other, a perceived lack of legitimacy of the project. These two dimensions, growth and democratic legitimacy, polarised the discourse.

Through its dynamic and multidimensional analysis of individual motivation and actor constellation, our case study reveals that the motives behind the protests against S21 involved strategic considerations, rather than the general refusal of the political process that 'post-political' theories have suggested.

As our study of evolving discourse coalitions shows, there was no single way of addressing the perceived lack of legitimacy in S21 plans. Instead, several different ways of tackling this issue emerged over time, including electoral and representative politics. Our analysis shows that the Green Party, which played an important role in connecting the opponents to S21 and their key issues, and which successfully pushed through a state-wide referendum, nonetheless had to continue with the megaproject they opposed, given the unexpected results in favour of S21. This, too, was democracy at work. The mediation process, electoral politics, and referendum show how several decision-making tools available to the political system were able to defuse the conflict. Our case study shows that the democratic deficits postulated by theories of the 'postpolitical' are not valid in the case of S21.

Admittedly, it is not advisable to draw general conclusions from a single case study, but despite certain limitations and biases implied by the methodology (e.g. newspaper data, coder-reliability) our study contributes to recent urban studies literature in several ways. First, our case study of S21 sheds light on the evolution and management of conflicts over megaprojects. Second, we show how research in urban politics and especially on megaprojects must look beyond the obvious facts and explicit statements, and go deeper to explore how political issues and concerns combine with relational social and political structures. In doing so, we complicate and qualify the arguments for a 'postpolitical' state of urban politics. Finally, future research should continue on this path of analysing the sources of strong discontent and polarisation, and investigate which issues specifically are the locus of disagreement.

\section{Acknowledgements}

We would like to thank Dorothy Kwek and Jennifer Spohrs for proofreading, and Christin Eckerle and Prema Hartkopf for assistance.

\section{Declaration of conflicting interests}

The author(s) declared no potential conflicts of interest with respect to the research, authorship, and/or publication of this article.

\section{Funding}

The author(s) received no financial support for the research, authorship, and/or publication of this article.

\section{Notes}

1. These were initially collected in a research project (Nagel, 2014) on the dynamics of the polarised discourse and the identification of the fields of conflict, and later published in 2016.

2. From www.philipleifeld.com.

3. Those issues include possible cost hikes and environmental damage.

4. www.visone.info.

5. http://visone.info/wiki/index.php/ Quick_layout.

\section{References}

Banister D and Hall P (1993) The second railway age. Built Environment 19(3/4): 156-162.

Barranco J and Wisler D (1999) Validity and systematicity of newspaper data in event analysis. European Sociological Review 16(3): 301-322.

Baumgarten B and Grauel J (2009) The theoretical potential of website and newspaper data for analysing political communication processes. Historical Social Research 34(1): 94-121. 
Beveridge R and Koch P (2017) The post-political trap? Reflections on politics, agency and the city. Urban Studies 54(1): 31-43.

Blühdorn I (2013) The governance of unsustainability: Ecology and democracy after the postdemocratic turn. Environmental Politics 22(1): 16-36.

Boland P (2014) The relationship between spatial planning and economic competitiveness: The 'path to economic nirvana' or a 'dangerous obsession'? Environment and Planning A 46: 770-787.

Bradford N (2016) Ideas and collaborative governance. Urban Affairs Review 52(5): S659-684.

Bulkeley H (2000) Discourse coalitions and the Australian Climate Change Policy Network. Environment and Planning C: Government and Policy 18(6): 727-748.

Bylund J (2012) Postpolitical correctness? Planning Theory 11(3): 319-327.

Crouch C (2004) Post-democracy. Cambridge: Polity Press.

Douglass M and Huang L (2007) Globalizing the city in southeast Asia: Utopia on the urban edge - The case of Phu My Hung, Saigon. International Journal of Asia-Pacific Studies 3: $1-42$.

Earl J, Martin A, McCarthy J, et al. (2004) The use of newspaper data in the study of collective action source. Annual Review of Sociology 30: $65-80$.

Fischer F (2003) Reframing Public Policy: Discursive Politics and Deliberative Practices. New York: Oxford University Press.

Fischer F and Forester J (ed) (1993) The Argumentative Turn in Policy Analysis and Planning. Durham, NC: Duke University Press.

Fisher DR, Leifeld P and Iwaki Y (2013) Mapping the ideological networks of American climate politics. Climatic Change 116(3): 523-545.

Franzosi R (1987) The press as a source of sociohistorical data: Issues in the methodology of data collection from newspapers. Historical Methods: A Journal of Quantitative and Interdisciplinary History 20(1): 5-16.

Franzosi R (2004) From Words to Numbers. Narrative, Data, and Social Science. Cambridge: Cambridge University Press.
Gissendanner S (2004) Mayors, governance coalitions, and strategic capacity. Drawing lessons from Germany for theories of urban governance. Urban Affairs Review 40(1): 44-77.

Graham S and Marvin S (2001) Splintering Urbanism: Networked Infrastructures, Technological Mobilities and the Urban Condition. Oxford: Blackwell.

Graham S and Marvin S (2003) Planning cybercities? Integrating telecommunications into urban planning. In: Helten $\mathrm{F}$ and Fischer B (eds) Envisioning Telecity: Towards the Urbanisation of ICT. New York: Peter Lang Publishing, pp. 23-59.

Hage P and Haray F (1983) Structural Models in Anthropology. Cambridge: Cambridge University Press.

Hajer M (1996) Ecological modernization as cultural politics. In: Lash S, Szerszynski B and Wynne B (eds) Risk, Environment and Modernity: Towards a New Ecology. London: SAGE Publications Ltd, pp. 246-268.

Hajer M (2002) Discourse analysis and the study of policy making. European Political Science 2(1): 61-65.

Hajer MA (1993) Discourse coalitions and the institutionalization of practice: The case of acid rain in Britain. In: Fischer $F$ and Forester $\mathrm{J}$ (eds) Discourse Coalitions and the Institutionalization of Practice: The Case of Acid Rain in Britain, The Argumentative Turn in Policy Analysis and Planning. Durham, NC, and London: Duke University Press, pp. 43-76.

Hajer MA (1995) The Politics of Environmental Discourse: Ecological Modernization and the Policy Process. Oxford: Claredon Press.

Hilgartner S and Bosk CL (1988) The rise and fall of social problems: A public arenas model. American Journal of Sociology 94(1): 53-78.

Hornig E-C (2017) Airport expansions and public protests - The democratic dilemma of vertically asymmetric policies. European Policy Analysis 3(2): 324-342.

Iacobucci D (1994) Graphs and matrices. In: Wassermann S and Faust K (eds) Social Network Analysis. Methods and Applications. Cambridge: Cambridge University Press, pp. 92-166.

Janning F, Leifeld P, Malang T, et al. (2009) Diskursnetzwerkanalyse. Überlegungen zur Theoriebildung und Methodik. In: Schneider V, 
Janning F, Leifeld P and Malang T (eds) Politiknetzwerke. Modelle, Anwendungen und Visualisierungen. Wiesbaden: VS Verlag für Sozialwissenschaften, pp. 59-92.

Jenkins-Smith HC, et al. (2014) The advocacy coalition framework: Foundations, evolution, and ongoing research. In: Sabatier PA and Weible C (eds) Theories of the Policy Process (3rd edn). Boulder, CO: Westview Press, pp. 183-223.

Jungherr A and Jürgens P (2014) Through a glass, darkly: Tactical support and symbolic association in Twitter messages commenting on Stuttgart 21. Social Science Computer Review 32(1): 74-89.

Kenis P and Schneider V (1991) Policy networks and policy analysis: Scrutinizing a new analytical toolbox. In: Marin B and Mayntz R (eds) Policy Networks: Empirical Evidence and Theoretical Considerations. Frankfurt am Main: Campus, pp. 25-59.

Koopmans R (1996) Explaining the rise of racist and extreme right violence in Western Europe: Grievances or opportunities? European Journal of Political Research 30(2): 185-216.

Koopmans R and Rucht D (1999) Protest event analysis - Where to now? Mobilization 4: 123-130.

Koopmans R and Statham P (1999) Political claims analysis: Integrating protest event and political discourse approaches. Mobilization 4(2): 203-221.

Kriesi H (ed.) (1995) New Social Movements in Western Europe: A Comparative Analysis. Volume 5. Minneapolis, MN: University of Minnesota Press.

Legacy C (2016) Transforming transport planning in the postpolitical era. Urban Studies 53(14): S3108-3124.

Leifeld P (2009) Die Untersuchung von Diskursnetzwerken mit dem Discourse Network Analyzer (DNA). In: Schneider V, et al. (eds) Politiknetzwerke. Modelle, Anwendungen und Visualisierungen. Wiesbaden: VS Verlag, pp. 391-404.

Leifeld P (2010) Political discourse networks: The missing link in the study of policy oriented discourse. Paper presented at the workshop 'Ideas, Policy Design and Policy Instruments: Casting Light on the Missing Link', ECPR
Joint Sessions of Workshops, Münster, 22-27 March. Available online at: http://www. philipleifeld.de.

Leifeld P (2012) Discourse Network Analyzer (DNA) manual. Bonn, Germany: Max Planck Institute for Research on Collective Goods. Available at: http://www.philipleifeld.de.

Leifeld P (2013) Reconceptualizing major policy change in the advocacy coalition framework. A discourse network analysis of German pension politics. The Policy Studies Journal 41(1): 169-198.

Leifeld P and Haunss S (2012) Political discourse networks and the conflict over software patents in Europe. European Journal of Political Research 51: 382-409.

McCann E (2017) Governing urbanism. Urban governance studies 1.0, 2.0 and beyond. Urban Studies 54(2): S312-326.

McCarthy JD, McPhail C and Smith J (1996) Images of protest: Dimensions of selection bias in media coverage of Washington demonstrations, 1982 to 1991. American Sociological Review 61(3): 478-499.

McCombs M and Shaw D (1972) The agendasetting function of mass media. Public Opinion Quarterly 36: 176-187.

MacLeod G (2011) Urban politics reconsidered: Growth machine to post-democratic city? Urban Studies 48(12): 2629-2660.

Maier T (2013) 'Stuttgart 21' im Spiegel von Facebook-Aktivitäten der Befürworter und der Gegner des Projektes. In: Brettschneider F and Schuster W (eds) Stuttgart 21. Ein Großprojekt zwischen Protest und Akzeptanz. Wiesbaden: Springer Fachmedien, pp. 77-96.

Marres N (2005) No issue, no public: Democratic deficits after the displacement of politics. $\mathrm{PhD}$ thesis, University of Amsterdam, The Netherlands [Cited from Legacy (2016)].

Mouffe C (2005) On the Political. London: Routledge.

Moulaert F, Rodriguez A and Swyngedouw E (eds) (2003) The Globalised City: Economic Restructuring and Social Polarization in European Cities. Oxford: Oxford University Press.

Moulaert F, Swyngedouw E and Rodriguez A (2001) Social polarization in metropolitan areas. European Urban and Regional Studies 8: 99-102. 
Muller A (2015) Using discourse network analysis to measure discourse coalitions: Towards a formal analysis of political discourse. World Political Science 11(2): 377-440.

Nagel M (2014) Polarisierung im politischen Diskurs. Eine Analyse dynamischer Wissen- und Diskursnetzwerke am Beispiel von 'Stuttgart'. PhD Dissertation, University of Konstanz.

Nagel M (2016) Polarisierung im politischen Diskurs. Eine Netzwerkanalyse zum Konflikt um 'Stuttgart'. Wiesbaden: Springer.

Novy J and Peters D (2013) Railway megaprojects as catalysts for the re-making of postindustrial cities? The case of Stuttgart 21 in Germany. In: Del Cerro Santamaría G (ed) Urban Megaprojects: A Worldwide View. Research in Urban Sociology 13. Bingley: Emerald Group Publishing, pp. 237-262.

Oosterlynck S and Swyngedouw E (2010) Noise reduction: The postpolitical quandary of night flights at Brussels airport. Environment and Planning A 42: 1577-1594.

Ortiz DG, Myers DD, Walls NE, et al. (2005) Where do we stand with the newspaper data? Mobilization: An International Journal 10: 397-419.

Rancière J (2001) Ten theses on politics. Theory and Event 5(3): 17-34.

Rancière J (2009) Hatred of Democracy. London: Verso.

Revelle W (2016) psych: Procedures for Personality and Psychological Research, Northwestern University, Evanston, Illinois, USA. Available at: https://CRAN.R-project.org/package $=$ psych $($ Version $=1.6 .12)$.

Rothmund T, Baumert A and Zinkernagel A (2014) The German 'Wutbürger': How justice sensitivity accounts for individual differences in political engagement. Social Justice Research 27(1): 24-44.

Rucht D, Koopmans R, Niedhardt F, et al. (1999) Acts of Dissent: New Developments in the Study of Protest. Oxford: Rowman \& Littlefield Publishers.

Salet W (2008) Rethinking urban projects. Experiences in Europe. Urban Studies 45(11): 2343-2363.

Schmidt VA (2008) Discursive institutionalism: The explanatory power of ideas and discourse. Annual Review of Political Science 11: 303326.

Schmidt VA and Radaelli CM (2004) Policy change and discourse in Europe: Conceptual and methodological issues. West European Politics 27(2): 183-210.

Swyngedouw E, Moulaert F and Rodriguez A (2002) Neoliberal urbanization in Europe: Large-scale urban development projects and the new urban policy. Antipode 34: 542-577.

Szarka J (2004) Wind power, discourse coalitions and climate change: Breaking the stalemate? European Environment 14(6): 314-330.

Vatter A and Heidelberger A (2013) Volksentscheide nach dem NIMBY-Prinzip? Eine Analyse des Abstimmungsverhaltens zu Stuttgart 21. (About the voting behavior and NIMBY effect). Politische Vierteljahresschrift 54(2): 317-336.

Vento AT (2017) Mega-project meltdown: Postpolitics, neoliberal urban regeneration and Valencia's fiscal crisis. Urban Studies 54(1): 68-84.

Young D and Keil R (2010) Reconnecting the disconnected: The politics of infrastructure in the in-between city. Cities 27: 87-95. 